\title{
THE RIGHT TO A NATIONALITY AND THE RIGHT TO ADEQUATE HOUSING: AN ANALYSIS OF THE INTERSECTION OF TWO LARGELY 'INVISIBLE' HUMAN RIGHTS VIOLATIONS
}

\author{
BENJAMIN GRONOWSKI*
}

\begin{abstract}
Millions of individuals around the world face challenges enjoying their right to a nationality, and millions more face challenges enjoying their right to adequate housing. While these human rights violations are recognised in general terms, little research has considered the extent to which these human rights abuses intersect as stateless persons face violations of specific socioeconomic rights, especially the right to adequate housing. This research attempts to fill that gap. This analysis explores the term adequate housing and the various legal instruments that enshrine this right, as well as the unique challenges faced by stateless persons in its enjoyment. This research argues that states have failed to respect, protect and fulfil the right to adequate housing for stateless persons in a number of contexts and that these failures are particularly acute for stateless persons with additional marginalised identities, which can then result in additional human rights violations. This analysis examines how previous policy solutions have failed to adequately consider the unique needs of inadequately housed stateless persons and calls attention to the need for more holistic and inclusive approaches to realise the right to adequate housing for all, which must include stateless persons.
\end{abstract}

\section{TABLE OF CONTENTS}

I Two 'Invisible' Human Rights Violations, Individually and Together. 240

II The Meaning of the Right to Adequate Housing and Its Protections According to Human Rights Law ...

III Challenges to Enjoying the Right to Adequate Housing for Stateless Persons and Further Legal Protections for Stateless Individuals

IV State Obligations Regarding the Right to Adequate Housing for Stateless Persons.

A The Obligation to Respect

B The Obligation to Protect......

C The Obligation to Fulfil

V Intersectional Identities and Statelessness: Further Discrimination in the Right to Adequate Housing.

VI The Interconnected Nature of Violations of the Right to Adequate Housing and Other Human Rights

VII Shortcomings of the Past and a Look to the Future 258

* Benjamin Gronowski is a recent graduate of the University of Minnesota's Humphrey School of Public Affairs, where he received the James Lyday Fellowship for Public Service and obtained his Master of Human Rights degree. He has researched and advocated for the right to a nationality at the Institute for Statelessness and Inclusion, as a Peace Corps Volunteer in the Dominican Republic, and in academia. 


\section{TOGETHER}

At least 15 million people are estimated to be stateless around the world, ${ }^{1}$ not considered nationals by any state under the operation of its laws according to the 1954 Convention Relating to the Status of Stateless Persons ('1954 Convention'). ${ }^{2}$ Yet attention to this issue has not necessarily matched the problem's scale, as the United Nations High Commissioner for Refugees has described stateless persons as "invisible," frequently living at the margins of society and the economy'. ${ }^{3}$ And while this is a critical human rights issue in itself, the violation of the right to a nationality is not the only rights abuse that stateless persons face. Due to the interrelated and interdependent nature of human rights, statelessness can be the cause and consequence of other rights violations, including civil and political rights and socioeconomic and cultural rights. Existing research on the rights violations faced by stateless persons has largely focused on civil and political rights, such as the right to move freely, participate politically and the constant threat and real peril of indefinite arbitrary detention. ${ }^{4}$ While some have considered the socioeconomic rights of stateless persons, these discussions are often limited. Rights violations are often wideranging and thus rarely analysed in great detail, instead referred to in general terms about the discrimination stateless persons face 'accessing basic rights'. 5 The barriers stateless children face in enjoying the right to education and the resulting impact this has on their futures is one of the few socioeconomic rights analysed in greater depth, ${ }^{6}$ as are the obstacles faced by stateless persons with regards to accessing medical care and enjoying the right to the highest attainable standard of health. ${ }^{7}$ The intersection of other socioeconomic rights and statelessness, such as the right to adequate housing, has not received the same level of consideration thus far. This analysis attempts to fill that void by highlighting the unique challenges faced by stateless persons in the enjoyment of the right to adequate housing. Through this examination, the author hopes to call attention to this human rights violation and prompt further investigation, which may ultimately result in greater respect and protection of the rights of stateless persons.

At the same time that millions are denied the right to a nationality, the United Nations estimates that over one billion people worldwide are not adequately

1 Institute on Statelessness and Inclusion, 'Executive Summary' in The World's Stateless (Wolf Legal Publishers 2014) 11.

2 Convention Relating to the Status of Stateless Persons, opened for signature 28 September 1954, 360 UNTS 117 (entered into force 6 June 1960) ('1954 Convention').

3 United Nations High Commissioner for Refugees, UNHCR Global Report 2007 (Annual Report, 2007) 39.

4 See, eg, Amal de Chickera and Nina Murray, Protecting Stateless Persons from Arbitrary Detention: An Agenda for Change (Report, European Network on Statelessness, 4 May 2017) 8.

5 Michelle Foster and Hélène Lambert, 'Statelessness as a Human Rights Issue: A Concept Whose Time Has Come' (2016) 28(4) International Journal of Refugee Law 564, 567.

6 Hernan Vales, 'Human Rights and Stateless Children' in Laura van Waas and Amal de Chickera (eds), The World's Stateless: Children (Wolf Legal Publishers 2017) 163.

7 Lindsey Kingston, Elizabeth Cohen and Christopher Morley, 'Debate: Limitations on Universality: The "Right to Health" and the Necessity of Legal Nationality' (2010) 10(11) BMC International Health and Hights $<$ https://www.ncbi.nlm.nih.gov/pmc/articles/PMC2894754/>. 
housed. ${ }^{8} 100$ million people around the world are thought to be homeless, ${ }^{9}$ untold millions live in conditions that threaten their health and human dignity, and millions more face forced evictions or threats of such evictions every year. ${ }^{10}$ Like the right to a nationality, the right to adequate housing is interconnected with other rights and can be the cause and consequence of additional human rights violations. Access to housing and proof of residency can be a requirement for the enjoyment of other rights, such as the right to work, to study, to vote or to privacy. ${ }^{11}$ Discrimination that deprives persons of adequate housing and subjects them to forced evictions can lead to the violation of these and other rights. Like those facing violations of the right to a nationality, persons experiencing violations of the right to adequate housing are often among societies' most marginalised; they have been described as 'invisible, banished to the peripheries of cities and towns, out of sight'. ${ }^{12}$ Certain populations are especially vulnerable to violations of this right, and it has been noted that 'women, children, youth, older persons, indigenous people, ethnic and other minorities, and other vulnerable individuals and groups all suffer disproportionately from the practice of forced evictions'. ${ }^{13}$ These groups are not just disproportionately vulnerable to forced evictions; rather, they are more likely to suffer a range of violations related to the right to adequate housing, which include living in substandard housing, residing in segregated areas without access to basic amenities, and homelessness or extreme housing insecurity. These groups are also often disproportionately affected by poverty and can face discrimination due to both poverty and their membership in one or many of these groups, which further limits enjoyment of the right to adequate housing. ${ }^{14}$ While it has been recognised that ethnic minorities and 'other vulnerable individuals and groups' are especially prone to violations of this right, ${ }^{15}$ and one might infer that stateless persons are included among these groups, little research has explicitly focused on the right to adequate housing for stateless persons.

These situations of invisibility intersect when stateless persons are denied the right to adequate housing. Stateless persons face discrimination and barriers imposed by both the state and private actors in initially accessing and remaining securely in adequate shelter. These include, but are not limited to, discriminatory lending practices, the threat and execution of forced evictions and physical

8 Miloon Kothari, Report of the Special Rapporteur on Adequate Housing as a Component of the Right to an Adequate Standard of Living, UN Doc E/CN.4/2005/48 (21 March 2005) 1, 2.

9 Committee on Economic, Social and Cultural Rights, Report on the Sixth Session, UN ESCOR, $6^{\text {th }}$ sess, Agenda Item 10, Supp No 3, UN Doc E/1992/23 (13 December 1991) 114 annex III (General Comment No 4: The Right to Adequate Housing (Art 11(1) of the Covenant)) [4] ('General Comment No 4').

10 Centre on Housing Rights and Evictions, Forced Evictions: Violations of Human Rights (Global Survey No 9, 2003) 12.

11 Office of the High Commissioner for Human Rights, The Right to Adequate Housing (Fact Sheet No 21, November 2009) 9 ('The Right to Adequate Housing').

12 Office of the High Commissioner for Human Rights, Info Note: Homelessness and Human Rights (A/HRC/31/54) (Report Summary, 2016) 2.

13 Committee on Economic, Social and Cultural Rights, UN ESCOR, $16^{\text {th }}$ sess, Supp No 2, UN Doc E/1998/22 (20 May 1997) 115 annex IV (General Comment No 7: The Right to Adequate Housing (Article 11.1 of the Covenant): Forced Evictions) [11] ('General Comment No 7').

14 Mutuma Ruteere, Report of the Special Rapporteur on Contemporary Forms of Racism, Racial Discrimination, Xenophobia and Racial Intolerance, UN GAOR, $68^{\text {th }}$ sess, Agenda Item 67(b), UN Doc A/68/333 (19 August 2013) 7 [20].

15 General Comment No 7, UN Doc E/1998/22 (n 13) 115 [11]. 
segregation from other communities. Stateless persons are then rarely able to benefit from legal recourse against discriminatory practices they face with regards to housing and other rights violations, which creates a cycle where those already most excluded from society face some of the greatest challenges in finding the means for inclusion. ${ }^{16}$ Furthermore, the lack of adequate housing can create additional barriers to employment or the enjoyment of other rights, such as the right to the highest attainable standard of health. This in turn furthers the cycle of poverty and inequality already experienced by stateless persons, which can lead to further exclusion. ${ }^{17}$ Both the right to a nationality and the right to adequate housing are referred to as preconditions for the enjoyment of other rights, with the right to a nationality described as the 'right to have rights' 18 and the right to adequate housing 'considered as a prerequisite for the enjoyment of civil and political rights'. ${ }^{19}$ While it is noted that these terms can create a false hierarchy of rights, they serve to underscore the importance of these rights and their impact on the enjoyment of other human rights. Denial of citizenship, barriers to adequate housing and poverty all create situations of further discrimination, stigmatisation and marginalisation. In combination, these factors increase the chances of intergenerational poverty, statelessness and further exclusion. ${ }^{20}$

Measuring the scope of violations of both the right to adequate housing and the right to a nationality is inherently difficult. There is insufficient data on those living in substandard housing, and especially for those experiencing homelessness. Some state that 'it is not possible at this stage to generate a defensible estimate of the global extent of homelessness'. ${ }^{21}$ And stateless persons are "almost by definition, "uncounted"".22 States deny their existence or ignore their presence, and fewer than half of all countries in the world have any data on stateless populations. ${ }^{23}$ The failure to sufficiently map the violation of either right individually creates additional challenges in understanding the degree to which the two categories overlap, and perhaps partially explains the lack of existing research. But the absence of data should not be a deterrent for attempting to understand the extent to which stateless persons face barriers in enjoying the right to adequate housing; rather, it should provide impetus to collect better data on both of these issues. This analysis will attempt to highlight and better understand the intersection of the right to a nationality and the right to adequate housing, and make those experiencing violations of both slightly less invisible. This study will first explore the term adequate housing and identify

16 Institute on Statelessness and Inclusion, Statelessness, Human Rights and the Sustainable Development Agenda (Working Paper, February 2017) 2 $<$ http://www.institutesi.org/SDG_working-paper2017.pdf $>$.

17 Jennifer Guay, 'How Being Stateless Makes You Poor' Foreign Policy (30 June 2016) $<$ https://foreignpolicy.com/2016/06/30/how-being-stateless-makes-you-poor/>.

18 Hannah Arendt, 'The Rights of Man: What Are They?' (1949) 3(1) Modern Review 467.

19 Miltiadis Sarigiannidis and Ioanna Pervou, 'Adequate Housing: Seeking Justiciability through the Right to Property' (2013) 1 International Journal of Human Rights and Constitutional Studies 27, 30.

20 Amal de Chickera, All about Statelessness: What Development Actors Need to Know (Wolf Legal Publishers 2017) 8.

21 Volker Busch-Geertsema, Dennis Culhane and Suzanne Fitzpatrick, 'Developing a Global Framework for Conceptualising and Measuring Homelessness' (2016) 55 Habitat International 124, 127.

22 Mark Manly and Santhosh Persaud, 'UNHCR and Responses to Statelessness' (2009) 32 Forced Migration Review 7, 7.

23 United Nations High Commissioner for Refugees, Global Trends: Forced Displacement in 2017 (Annual Report, 2017) 51 ('Global Trends'). 
where international law enshrines this right. It will then examine its application for stateless persons and states' failures to meet their obligations. This analysis will highlight how certain groups of stateless persons are particularly vulnerable to the contravention of their right to adequate housing and how these violations can result in additional human rights abuses. This study ends by highlighting the futility of previous attempts to address rights violations independently and calls attention to the need for more holistic and inclusive approaches to truly realise the right to adequate housing for all.

\section{The Meaning of the Right to Adequate Housing And Its}

\section{Protections ACCORDING TO HUMAN RightS LAW}

Before analysing states' shortcomings with regard to the right to adequate housing for stateless persons, it is useful to define this term and differentiate it from similar rights. The Committee on Economic, Social and Cultural Rights ('CESCR') in its General Comments provides the greatest clarity on this right's protections and corresponding state obligations. ${ }^{24}$ The CESCR stresses that the right to housing should not be interpreted narrowly or equated simply with a roof over one's head; rather, it must mean adequate housing that provides for physical needs such as security, psychological needs such as privacy, and social needs such as those of the family. ${ }^{25}$ In order for housing to be adequate, it must meet the following criteria: legal security of tenure; availability of services, materials, facilities and infrastructure; affordability; habitability; accessibility; location; and cultural adequacy. ${ }^{26}$ This right differs from the right to property, which is also protected in international law, in that it provides for broader protections and is intended to ensure that everyone has access to secure housing, regardless of ownership. ${ }^{27}$ CESCR General Comment 7 elaborates that 'all persons should possess a degree of security of tenure which guarantees legal protection against forced eviction, harassment and other threats'. ${ }^{28}$ If focused exclusively on legal property ownership, one might overlook the rights of tenants or the forced eviction of those residing on private property without legal title. This is not to say that there is no connection between the right to adequate housing and the right to property, as these rights are often inextricably linked. Indeed, the right to property has been used to provide means for the justiciability of the right to adequate housing, ${ }^{29}$ although this interpretation is generally narrower. The right to adequate housing also differs from the right to land. While the Special Rapporteur on Adequate Housing as a Component of the Right to an Adequate Standard of Living, and on the Right to Non-Discrimination in this Context ('Special Rapporteur on Adequate Housing') has appealed to the Human Rights Council to recognise the right to land due to its integral connection to the right to adequate housing and other rights, it has not yet been recognised as such. ${ }^{30}$

24 General Comment No 4, UN Doc E/1992/23 (n 9); General Comment No 7, UN Doc $\mathrm{E} / 1998 / 22$ (n 13).

25 General Comment No 4, UN Doc E/1992/23 (n 9) 115 [6]-[7].

26 ibid 116-17 [8].

27 Jessie Hohmann, The Right to Housing: Law, Concepts, Possibilities (Hart Publishing 2013) 128.

28 General Comment No 7, UN Doc E/1998/22 (n 13) 113 [1].

29 Sarigiannidis and Pervou (n 19) 37.

30 Miloon Kothari, Report of the Special Rapporteur on Adequate Housing as a Component of the Right to an Adequate Standard of Living, UN GAOR, $4^{\text {th }}$ sess, Agenda Item 2, UN Doc A/HRC/4/18 (5 February 2007) 10-11 [25]-[31]. 
Land, like property, is a critical component of this right, but the right to adequate housing is understood to provide greater protections and be more allencompassing. As such, this analysis will focus on the right to adequate housing and use this term throughout.

The right to adequate housing is enshrined extensively in international, regional and national laws, even if states do not always honour these obligations. This right is first recognised in art 25 of the Universal Declaration of Human Rights, which states 'everyone has the right to a standard of living adequate for the health and well-being of himself and of his family, including ... housing', 31 Binding international law reiterates this right in the International Covenant on Economic, Social and Cultural Rights ('ICESCR'), which recognises

the right of everyone to an adequate standard of living for himself and his family, including ... housing, and to the continuous improvement of living conditions. The State Parties will take appropriate steps to ensure the realization of this right $\ldots^{32}$

The right to adequate housing is also addressed directly or indirectly in other binding human rights treaties, including art 5 of the International Convention on the Elimination of All Forms of Racial Discrimination ('CERD'), which compels state parties to 'prohibit and eliminate racial discrimination in all its forms and to guarantee the right of everyone, without distinction as to race, colour, or national or ethnic origin, to equality before the law, notably in the enjoyment of ... the right to housing,' 33 and in the International Covenant on Civil and Political Rights' ('ICCPR') protections against the arbitrary and unlawful interference with one's privacy or home. ${ }^{34}$

This right is further enshrined in international treaties providing protections for particular groups. The Convention on the Elimination of All Forms of Discrimination against Women (' $C E D A W$ ') states that women should 'enjoy adequate living conditions, particularly in relation to housing' 35 and that women have equal rights to conclude contracts. ${ }^{36}$ The Convention on the Rights of the Child (' $C R C$ ') contains protections for children from arbitrary and unlawful interference with their privacy or homes and obligates states to 'recognize the right of every child to a standard of living adequate for the child's physical, mental, spiritual, moral and social development'. ${ }^{37}$ The $C R C$ further obligates states to take appropriate measures to assist those responsible for children in implementing the right to adequate housing by providing material assistance and support programs. ${ }^{38}$ The Convention on the Rights of Persons with Disabilities

31 Universal Declaration of Human Rights, GA Res 217A (III), UN GAOR, UN Doc A/810 (10 December 1948) art 25.

32 International Covenant on Economic, Social and Cultural Rights, opened for signature 16 December 1966, 993 UNTS 3 (entered into force 3 January 1976) art 11 ('ICESCR').

33 International Convention on the Elimination of All Forms of Racial Discrimination, opened for signature 21 December 1965, 660 UNTS 195 (entered into force 4 January 1969) art 5.

34 International Covenant on Civil and Political Rights, opened for signature 16 December 1966, 999 UNTS 171 (entered into force 23 March 1976) art 17 ('ICCPR').

35 Convention on the Elimination of All Forms of Discrimination against Women, opened for signature 18 December 1979, 1249 UNTS 13 (entered into force 3 September 1981) art 14.

36 ibid art 15.

37 Convention on the Rights of the Child, opened for signature 20 November 1989, 1577 UNTS 3 (entered into force 2 September 1990) arts 16, 27 (' $C R C$ ').

38 ibid. 
('CRPD') provides for equal access to housing for persons with disabilities ${ }^{39}$ and obligates states to continuously improve living conditions and safeguard and promote this right without discrimination, as well as ensure access to housing programs. ${ }^{40}$ The International Convention on the Protection of the Rights of All Migrant Workers and Members of Their Families states that migrant workers shall enjoy equal treatment with regards to housing access and protection against housing-related exploitation. ${ }^{41}$ These protections are especially important for individuals who belong to these groups and are also stateless or at risk of statelessness, as they face additional challenges enjoying the right to adequate housing, which this analysis will explore in a later Part.

The right to adequate housing is further protected in regional treaties, including the 1996 revised European Social Charter, ${ }^{42}$ the African Charter on the Rights and Welfare of the Child, ${ }^{43}$ and the Charter for the Organization of American States. ${ }^{44}$ Even regional treaties that do not directly refer to this right, such as the American Convention on Human Rights and the African Charter on Human and Peoples' Rights, have been interpreted to include protections related to the right to adequate housing as derived from other rights, such as the right to privacy or property. ${ }^{45}$ The right to adequate housing is additionally enshrined in states' constitutions, and fifty-two national constitutions address the right to adequate housing, either explicitly referring to this right or noting the state's general responsibility to ensure adequate housing and living conditions for its population. ${ }^{46}$ Like the right to a nationality, every state is party to at least one treaty committing itself to respect and protect the right to adequate housing, without discrimination on any ground, including 'race, colour, sex ... national or social origin ... or birth or other status' ${ }^{47}$ As such, the lack of a nationality and underlying discriminatory factors, such as race or sex, cannot be the reason for unequal treatment with regards to the right to adequate housing. While the right to adequate housing is extensively enshrined in international and domestic law, stateless persons face a number of challenges enjoying this fundamental right.

39 Convention on the Rights of Persons with Disabilities, GA Res 61/106, UN GAOR, 61 ${ }^{\text {st }}$ sess, Agenda Item 67(b), UN Doc A/RES/61/106 (24 January 2007, adopted 13 December 2006) art 9.

40 ibid art 28.

41 International Convention on the Protection of the Rights of All Migrant Workers and Members of Their Families, opened for signature 18 December 1990, 2220 UNTS 3 (entered into force 1 July 2003) art 43.

42 European Social Charter (Revised), opened for signature 3 May 1996, ETS No 163 (entered into force 1 July 1999) arts 30, 31.

43 African Charter on the Rights and Welfare of the Child, opened for signature 11 July 1990, OAU Doc CAB/LEG/24.9/49 (entered into force 29 November 1999) art 20.

44 Charter of the Organization of American States, opened for signature 30 April 1948, 119 UNTS 3 (entered into force 13 December 1951) art 34.

45 The Right to Adequate Housing (n 11) 12.

46 Scott Leckie, 'The Justiciability of Housing Rights' in SIM Special No 18: Proceedings of the Conference on Optional Protocol to the Covenant of Economic, Cultural and Social Rights (Netherlands Institute on Human Rights 1995) 35-77.

$47 \quad \operatorname{ICESCR}$ (n 32) art 2. 


\section{Challenges to EnJoying the Right to AdeQuAte Housing For}

\section{Stateless Persons and Further Legal Protections for Stateless}

\section{INDIVIDUALS}

For stateless persons or those at risk of statelessness, enjoying the internationally protected right to adequate housing and each component of this right as elaborated by the CESCR (legal security of tenure; availability of services, materials, facilities and infrastructure; affordability; habitability; accessibility; location; and cultural adequacy) brings its own set of challenges. Stateless persons are often barred from renting or owning property due to outright discrimination or logistical hurdles stemming from their lack of identity documents, which can be required of tenants and potential buyers. They may then be forced to squat on land for lack of other options, where they are then subject to threats, harassment and forced evictions, in violation of the principle of security of tenure. ${ }^{48}$ The housing that stateless persons can access is often substandard with limited access to safe drinking water, adequate sanitation or refuse disposal, in violation of the principle of availability of services. ${ }^{49}$ Stateless persons often face excessive rents and rent increases, and they may have few alternatives or options for recourse from unscrupulous landlords, in violation of the principle of affordability. ${ }^{50}$ Accessible housing for stateless persons is often overcrowded due to high poverty levels, and of such a poor quality that provides limited protection from the elements and exposure to additional health hazards, in violation of the principle of habitability. ${ }^{51}$ Instead of ensuring that stateless persons, as a 'disadvantaged group', are 'ensured some degree of priority consideration in the housing sphere' in law and policy, states often ignore or actively exclude them, in violation of the principle of accessibility. ${ }^{52}$ Stateless persons are often pushed to the most marginal and remote lands in both urban and rural areas with limited access to facilities and services, in violation of the principle of location. ${ }^{53}$ Due to the discrimination stateless persons already face, they are often unable or unwilling to express their cultural identity in housing, in violation of the principle of cultural adequacy. ${ }^{4}$ Stateless persons face challenges enjoying each component part of the right to adequate housing, as well as broader principles of equality and non-discrimination, which underpin the human rights covenants. 55

While stateless persons face challenges enjoying the right to adequate housing in numerous countries, those obstacles vary depending on context. In locations with sizeable stateless populations facing active repression, such as Myanmar, stateless Rohingya not displaced internationally are confined to isolated communities without adequate services or freedom of movement. ${ }^{56}$ This contravenes the principles of availability of services, habitability and location.

General Comment No 4, UN Doc E/1992/23 (n 9) 115-16 [8].

ibid 116 [8].

ibid.

ibid.

ibid.

ibid.

ibid.

ICESCR (n 32), art 2; ICCPR (n 34) arts 2, 26.

56 Human Rights Council, Report of the Special Rapporteur on the Situation of Human Rights in Myanmar, UN GAOR, 40 ${ }^{\text {th }}$ sess, Agenda Item 4, UN Doc A/HRC/40/68 (2 May 2019) 9 [37]. 
Furthermore, fearing for their safety, ${ }^{57}$ they are less likely to express their cultural identity, in violation of the principle of cultural adequacy. In countries where statelessness depends on individual access to identity documents, as opposed to complete bans based on ethnicity, such as the Roma of North Macedonia, the challenges are distinct but no less important. Here, individuals face discrimination primarily from private actors in renting housing or they are unable to afford formal housing, forcing them to live in informal or unauthorised settlements without adequate services. ${ }^{58}$ This is in violation of the principles of security of tenure, availability of services and affordability. Although there is variation based on the nature of the violation of the right to a nationality, stateless persons face a host of challenges enjoying the right to adequate housing.

While the 1954 Convention was written to provide protections for stateless persons and includes stipulations in regards to the right to adequate housing, its protections are fairly minimal. Article 21 states:

As regards housing, the Contracting States, in so far as the matter is regulated by laws or regulations or is subject to the control of public authorities, shall accord to stateless persons lawfully staying in their territory treatment as favourable as possible and, in any event, not less favourable than that accorded to aliens generally in the same circumstances. ${ }^{59}$

Like art 21, art 13 provides that the treatment of stateless persons be as favourable as possible and no less favourable than that accorded to aliens with 'regards the acquisition of movable and immovable property and other rights pertaining thereto, and to leases and other contracts relating to movable and immovable property'. ${ }^{60}$ Given that the 1954 Convention distinguishes between the rights afforded to nationals and non-nationals and requires the presence of stateless persons to be considered lawful by the state to enjoy these rights, its protections are conditional and minimal, and thus should not be relied on exclusively by those defending the right of stateless persons to adequate housing. But while these safeguards are provisional, other international treaties providing for the right to adequate housing are not, as has been further clarified by their respective monitoring bodies. These provide a stronger foundation for the right to adequate housing for all individuals, including stateless persons.

As the ICESCR provides some of the broadest protections with regards to the right to adequate housing, it is a natural starting place to understand international safeguards for stateless persons apart from the 1954 Convention. CESCR General Comment 20 specifies that the rights enumerated in the ICESCR, including the right to adequate housing, apply to all persons regardless of nationality. The Committee goes on to state that ' $[\mathrm{t}]$ he ground of nationality should not bar access to Covenant rights' 61 and 'Covenant rights apply to everyone including non-nationals, such as ... stateless persons ... regardless of legal status and documentation'. ${ }^{62}$ While some may note that ICESCR art 4

57 ibid 11.

58 United Nations High Commissioner for Refugees, 'This is Our Home' Stateless Minorities and Their Search for Citizenship (Report 3 November 2017) 24.

591954 Convention (n 2) art 21.

60 ibid art 13.

61 Committee on Economic, Social and Cultural Rights, General Comment No 20: NonDiscrimination in Economic, Social and Cultural Rights (Art 2, Para 2, of the International Covenant on Economic, Social and Cultural Rights), UN ESCOR, 42 ${ }^{\text {nd }}$ sess, Agenda Item 3 , UN Doc E/C.12/GC/20 (2 July 2009) 9 [30].

62 ibid. 
allows for limitations to these rights, and thus potentially limitations on states' obligations to stateless persons, the ICESCR allows only for 'limitations as are determined by law only in so far as this may be compatible with the nature of these rights and solely for the purpose of promoting the general welfare in a democratic society'. ${ }^{63}$ As such, limitations designed to reduce duties to a select portion of states' population run contrary to their obligations of nondiscrimination and advancing the general welfare. In situations where states are unable to improve housing conditions for their entire population, the CESCR notes that 'obligations under the Covenant continue to apply and are perhaps even more pertinent during times of economic contraction' 64 and, furthermore, 'state parties must give due priority to those social groups living in unfavourable conditions by giving them particular consideration', ${ }^{65}$ rather than further benefiting already advantaged groups. As such, limitations on states' obligations that fail to consider and prioritise the unique and often disadvantaged positions of stateless persons run counter to states' human rights obligations.

Other bodies apart from the CESCR have provided further clarification on states' obligations regarding the right to adequate housing for this population. In General Comment 15, the Human Rights Council declares that possession of a nationality does not impact the possession of the rights outlined in the ICCPR and that '[i]n general, the rights set forth in the Covenant apply to everyone, irrespective of reciprocity, and irrespective of his or her nationality or statelessness'. 66 The Committee on the Rights of the Child pronounces in General Comment 6 that 'the enjoyment of rights stipulated in the Convention is not limited to children who are citizens of a State party and must therefore ... also be available to all children ... irrespective of their nationality, immigration status or statelessness'. ${ }^{67}$ The Committee on the Elimination of Discrimination against Women ('CEDAW') calls attention to the additional barriers faced by stateless women in the enjoyment of their rights as they face discrimination based on both gender and nationality. CEDAW General Recommendation 32 establishes state parties' 'obligations to respect, protect and fulfil the rights of refugee, asylum-seeking and stateless women to non-discrimination and substantive equality', ${ }^{68}$ including in the right to adequate housing. While the 1954 Convention may be criticised for the exceptions it provides regarding states' obligations and its narrow applicability due to limited ratification, other widely-ratified treaties provide broad protections with regards to the right to adequate housing for stateless persons. But while numerous treaties and their respective monitoring bodies have emphasised that the right to adequate housing applies to all persons, regardless of nationality, states have often failed to live up to their obligations for stateless persons.

$63 \quad I C E S C R$ (n 32) art 4.

64 General Comment No 4, UN Doc E/1992/23 (n 9) 117 [11].

65 ibid.

66 Human Rights Committee, CCPR General Comment No 15: The Position of Aliens Under the Covenant, $27^{\text {th }}$ sess (11 April 1986) [1], cited in Compilation of General Comments and General Recommendations Adopted by Human Rights Treaty Bodies, UN Doc HRI/GEN/1/Rev.5 (26 April 2001) 127.

67 Committee on the Rights of the Child, General Comment No 6 (2005): Treatment of Unaccompanied and Separated Children Outside their Country of Origin, $39^{\text {th }}$ sess, UN Doc CRC/GC/2005/6 (1 September 2005) 7 [12].

68 Committee on the Elimination of Discrimination against Women, General Recommendation No 32 on the Gender-Related Dimensions of Refugee Status, Asylum, Nationality and Statelessness of Women, UN Doc CEDAW/C/GC/32 (14 November 2014) 2 [4]. 


\section{State Obligations Regarding the Right to Adequate Housing for}

\section{STATELESS PERSONS}

As alluded to by CEDAW General Recommendation 32 and further detailed in customary international law, states are obligated to take steps to respect, protect, and fulfil their obligations towards rights holders. This includes the right to adequate housing for stateless persons. These obligations do not mean that states are immediately burdened with constructing housing for all persons on their territories, rather, it means that states are required to take steps towards the progressive realisation of this right, to the maximum of their available resources. ${ }^{69}$ But while many obligations regarding the right to adequate housing are gradual, some are immediate. ${ }^{70}$ States are obligated to guarantee nondiscrimination in housing; they are also obligated to work to map the extent of homelessness and inadequate housing, prevent forced evictions and guarantee a degree of security of tenure. States with sizeable stateless populations have often failed to even meet these immediate minimum core obligations since stateless persons live unrecognised in their territories, in substandard housing and at risk of forced eviction. CESCR General Comment 3 states that if 'any significant number of individuals is deprived ... of basic shelter and housing, ... [the state] is, prima facie, failing to discharge its obligations under the Covenant'. ${ }^{71} \mathrm{By}$ depriving a significant number of stateless individuals of basic housing, states are failing to discharge both their minimum core obligations and live up to further commitments towards the progressive realisation of this right.

The following instances highlight both the widespread nature of this rights violation and the complexity of the issue. Due to limitations of existing data, challenges of self-identification, the extent of the problem and uncertainty in laws and their application, not all groups or their members necessarily identify as stateless or are considered in the following. These instances are intended to be illustrative of state failures in their obligations to respect, protect and fulfil the rights of stateless persons and those at risk of statelessness, and are not comprehensive.

\section{A The Obligation to Respect}

State obligations to respect the right to adequate housing entail refraining from direct or indirect interference with this right through legal measures, policies or practices. ${ }^{72}$ This entails abstaining from arbitrary or forced evictions that are contrary to international law of any persons or groups. ${ }^{73}$ It includes refraining from the destruction or demolition of homes. ${ }^{74}$ Respecting this right involves not discriminating against certain groups in their access to and control over housing, land and property. Additionally, state obligations to respect the right to adequate

$69 \operatorname{ICESCR}$ (n 32) art 2.

70 General Comment No 4, UN Doc E/1992/23 (n 9) 117 [10].

71 Committee on Economic, Social and Cultural Rights, Report on the Fifth Session, $5^{\text {th }}$ sess, Supp no 3, UN Doc E/1991/23 (14 December 1990) annex III (General Comment No 3: The Nature of States Parties' Obligations (Art 2, Para 1, of the Covenant)) 86 [10].

72 Arturs Kucs, Zane Sedlova and Liene Pierhurovica, 'The Right to Housing: International, European and National Perspectives' (2008) 64/65 Cuadernos Constitucionales de la Cátedra Fadrique Furió Ceriol 101, 103.

73 General Comment No 7, UN Doc E/1998/22 (n 13) 114-115 [9]-[10].

74 ibid 116 [13]. 
housing include not denying security of tenure to particular groups, not infringing on the right to privacy via entry and searches by police, and not actively polluting or exposing certain groups to contaminants and health hazards.

States have failed to respect the right to adequate housing of stateless persons in both obvious and more nuanced ways. A direct example of state failure to respect this right is when the state subjects stateless persons to forced evictions without the appropriate procedural protections laid out in CESCR's General Comment 7, such as exploring alternatives, providing adequate notice, or offering legal recourse or remedy. ${ }^{75}$ In extreme cases, such as the Rohingya in Myanmar, state agents have destroyed or been involved in the destruction of the homes of stateless persons through demolition and arson. ${ }^{76}$ The state has also failed to respect this right by refusing access to previously occupied housing and land following the displacement of stateless populations. ${ }^{77}$ In cases where the stateless population is increasingly viewed as foreign and subject to arbitrary deprivation of nationality, such as the Rohingya or persons of Haitian descent in the Dominican Republic, or Iraqi Kurds, stateless persons can face eviction and then subsequent deportation to neighbouring countries. ${ }^{78}$ In Kuwait, stateless Bidoons have been ordered to abandon government-provided housing, which was formerly available to them. ${ }^{79}$

Additionally, states have failed in their obligations to respect this right for stateless persons in more indirect ways. States may force stateless persons to live in the least desirable areas of cities or regions, where they are exposed to pollution and health hazards from government-owned and -run factories and power plants. States have indirectly failed to respect this right by pushing stateless persons to areas without access to services or failing to provide services to areas with existing concentrations of stateless persons. In Turkmenistan, 76\% of those in northern regions lack access to piped drinking water and these are the same regions of the country where most stateless persons live. ${ }^{80}$ These persons are instead forced to rely on open sources of water, which contain high levels of saline, are susceptible to pollution and are more likely to carry disease. But states have failed stateless persons in other ways, apart from directly or indirectly interfering with their right to adequate housing.

\section{B The Obligation to Protect}

State obligations to protect the right to adequate housing entail that the state prevent non-state actors from interfering with this right. These actors may

75 ibid 116 [14].

76 'Burma: Scores of Rohingya Villages Bulldozed', Human Rights Watch (online, 23 February 2018) <https://www.hrw.org/news/2018/02/23/burma-scores-rohingya-villagesbulldozed $>$.

77 Simon Lewis, 'After Alleged Ethnic Cleansing, Myanmar Will Takeover the Burned Land That Rohingya Muslims Fled', Business Insider (online, 27 September 2017) $<$ https://www.businessinsider.com/r-government-will-take-over-burned-myanmar-landminister-2017-9? IR=T>.

78 'Haiti/Dominican Republic: Reckless Deportations Leaving Thousands in Limbo' Amnesty International (online, 15 June $<$ https://www.amnesty.org/en/latest/news/2016/06/haiti-dominican-republic-recklessdeportations-leaving-thousands-in-limbo/>.

79 Human Rights Watch, The Bedoons of Kuwait: Citizens without Citizenship (Report, August $1995)<$ https://www.hrw.org/reports/1995/Kuwait.htm> ('Bedoons of Kuwait Report').

80 Marjorie Farquharson, Statelessness in Central Asia (Report, United Nations High Commissioner for Refugees May 2011) 56. 
include landlords, landowners, property developers and corporations. ${ }^{81}$ To protect this right, the state must ensure that landlords do not discriminate against particular groups and that private actors do not carry out forced evictions. Thirdparty evictions may be executed for a variety of reasons, including infrastructure projects, urban renewal projects, large-scale agriculture projects, and international events such as the Olympics or the World Cup. They may be done individually by corporations or in tandem with the state, or performed by private citizens. Additional obligations to protect include ensuring that when private entities provide services such as water and sanitation, they are available to all, of adequate quality, and are not subject to arbitrary withdrawal. ${ }^{82}$ Furthermore, the state should prevent discriminatory practices that affect certain groups' access to, and control over, housing, land and property, such as financial institutions' equal extension of housing finance to all. If infringements on the right to adequate housing do occur, the state must prevent further violations and guarantee access to legal remedies and redress for those affected. ${ }^{83}$

States have failed to protect the right to adequate housing of stateless persons across a variety of contexts, from violations by both individual and collective actors. Individual landlords violate stateless persons' right to adequate housing when they deny rental applications initially or rescind rental agreements upon discovery that they lack proof of a nationality. ${ }^{84}$ In Slovenia, even after successfully purchasing land or property, Roma have been prevented from settling there by non-Roma neighbours. ${ }^{85}$ In Turkey, the state has failed to protect stateless persons from the destruction of key elements of adequate housing by members of nearby communities, such as the demolition of drainage systems. ${ }^{86}$ In the case of the Roma, it can be challenging to disentangle discrimination faced in accessing adequate housing due to their ethnicity or statelessness, but regardless the state has obligations to protect this right for all persons. In Nepal, patriarchal citizenship and land ownership systems deny women the ability to pass their citizenship to their children, deny women equal land ownership rights and deny those without nationality the right to own property. ${ }^{87}$ Due to unequal laws that fail to protect women from land seizures by spouses and family, men in Nepal own $90 \%$ of the land and $94 \%$ of the country's properties. $^{88}$

The state has failed to protect stateless persons from violations of the right to adequate housing not just from individuals such as landlords, neighbours and family members, but also collective actors. Infrastructure projects funded by

81 Kucs, Sedlova and Pierhurovica (n 72) 103.

82 The Right to Adequate Housing (n 11) 33.

83 National Law Center on Homelessness \& Poverty, Housing Rights for All: Promoting and Defending Housing Rights in the United States ( $5^{\text {th }}$ edn, National Law Center on Homelessness \& Poverty 2011) 34.

84 Ulaş Karan, Ignored and Unequal: Roma Access to the Right to Housing and Education in Turkey (Report, Minority Rights Group International June 2017) 10.

85 Tatjana Perić, 'Insufficient: Governmental Programmes for Roma in Slovenia', European Roma Rights Center (online, 15 August 2001) <http://www.errc.org/roma-rightsjournal/insufficient-governmental-programmes-for-roma-in-slovenia>.

86 Karan (n 84) 11.

87 Food and Agriculture Organization of the United Nations, 'Gender and Land Rights Database: Nepal' Food and Agriculture Organization of the United Nations Country Profiles (Webpage) <http://www.fao.org/gender-landrights-database/countryprofiles/countries-list/national-legal-framework/womens-property-and-use-rights-inpersonal-laws/en/?country_iso3=NPL $>$.

88 Katharina Borchardt, 'Nepal: Women Demand Land Rights' $D W$ (online, 9 December 2009) $<$ https://www.dw.com/en/nepal-women-demand-property-rights/a-4464873>. 
international investors such as the Tokwe Mukosi Dam in Zimbabwe have displaced tens of thousands and destroyed existing housing, although it is difficult to say who among the displaced is stateless or at risk of statelessness. ${ }^{89}$ In Turkey, the state has failed to respect and protect Roma from forced evictions and housing destruction to make way for urban renewal projects undertaken in public-private partnership. ${ }^{90}$ In Cambodia, ethnic Vietnamese face evictions carried out by groups of citizens, along with those performed jointly by the state and private developers. ${ }^{91}$ In some regions of the country 'evictions occur through private sector mechanisms and development projects which displace entire waterside communities' 92 made up predominantly of ethnic Vietnamese who are stateless or at risk of statelessness.

Following the violation of their right to adequate housing by private individuals or collective entities, stateless persons are often unable or unwilling to seek legal remedy. This may be due to fear of further persecution by the same actors following state ambivalence or additional oppression by the state after identifying themselves and their place of residence, as they may now be subject to arbitrary arrest and detention. While this inability or unwillingness varies by location, it is understandably more prevalent in locations where statelessness is widespread and groups face systematic denials of their right to a nationality, as opposed to locations where statelessness occurs on a more individual basis. The Bidoon of Kuwait are one such group that face state persecution, although not necessarily for having availed themselves to its protection following violations of the right to adequate housing; rather they live under 'self-imposed house arrest' 93 for fear of detention upon leaving their homes. ${ }^{94}$ But states' obligations towards stateless persons go beyond simply avoiding direct obstruction and preventing others from interfering with the enjoyment of their rights.

\section{The Obligation to Fulfil}

States also have obligations to fulfil the right to adequate housing for all persons on their territories by adopting positive legislative, administrative, judicial and promotional measures. As CESCR General Comment 4 notes, these changes in policy and administration should target disadvantaged groups and provide them with some degree of priority consideration. ${ }^{95}$ The Special Rapporteur on Adequate Housing has also noted that:

[S]ome differential treatment or special measures [may be necessary] in order to obtain substantive equal treatment, putting all members of the community on an equal footing. States are required to take affirmative action to attenuate or

89 'Homeless, Landless, and Destitute: The Plight of Zimbabwe's Tokwe-Mukorsi Flood Victims', Human Rights Watch (online, February 2015).

90 Karan (n 84) 14.

91 Laurie Parsons and Sabina Lawreniuk, 'Seeing Like the Stateless: Documentation and the Mobilities of Liminal Citizenship in Cambodia’ (2018) 62(1) Political Geography 1, 8.

92 ibid.

93 Bedoons of Kuwait Report (n 79).

94 United Kingdom Home Office, Country Information and Guidance Kuwait: Bidoons (Country Policy and Information Notes Version 2.0, July 2016) $<$ https://assets.publishing.service.gov.uk/government/uploads/system/uploads/attachment_d ata/file/566157/CIG___Kuwait_-_Bidoons.pdf>.

95 General Comment $\overline{N o} \overline{4}$, UN Doc E/1992/23 (n 9) 117 [11]. 
suppress the conditions that perpetuate discrimination and to rectify its cumulative adverse effects on housing. ${ }^{96}$

These affirmative actions include the development of national housing plans that prioritise those most disadvantaged by identifying the necessary resources for their implementation, outlining performance measures and monitoring results. ${ }^{97}$ States are also obligated to work progressively given their resource constraints to address homelessness, improve essential physical infrastructure, and provide public housing and housing subsidies for those unable to otherwise enjoy the right to adequate housing. ${ }^{98}$

States are obligated to fulfil the right to adequate housing by giving priority consideration for the most disadvantaged, a category which must include stateless persons, but they have often failed to do so for this group. This is unsurprising given that states are often hesitant to recognise that stateless persons exist in their borders at all, but this does not relieve them of their obligations to prioritise them and other disadvantaged groups. In some cases, instead of addressing homelessness among the stateless and fulfilling the right to adequate housing, the state has actively persecuted stateless persons and rendered them homeless. This is evidenced by the experiences of the Rohingya in Myanmar or those expelled from housing in Kuwait. Even when the state has not actively destroyed the homes of stateless persons or evicted them, stateless persons are often still barred from accessing housing services and initiatives.

While states might argue that they are taking steps to fulfil their obligations to all, closer inspection shows that this is often not the case for stateless persons. In some situations, such as the Nubians of Kenya, the government has displaced stateless persons and other low-income residents to build affordable public housing, but then never allowed those displaced to benefit from these programs. ${ }^{99}$ Thus, even when housing projects are undertaken in areas with high concentrations of stateless persons, they can fail to benefit those individuals and instead simply be located in the same geographical area as the stateless. ${ }^{100} \mathrm{In}$ Bangladesh, camps that have existed since 1980 and are home to predominantly Urdu-speaking individuals still lack basic amenities and have limited access to sanitation, water and garbage disposal after nearly forty years of occupation. ${ }^{101}$ In Italy, Roma are often effectively excluded from accessing social housing due to the allocation criteria used by the social housing system. ${ }^{102}$ Additionally, in Slovenia, it has been noted that

96 Raquel Rolnik, Report of the Special Rapporteur on Adequate Housing as a Component of the Right to an Adequate Standard of Living, UN GAOR, $65^{\text {th }}$ sess, Agenda Item 69 (b), UN Doc A/65/261 (9 August 2010) 10.

97 The Right to Adequate Housing (n 11) 34.

98 Kucs, Sedlova and Pierhurovica (n 72) 104.

99 Abraham Korir Sing'oei, 'Promoting Citizenship in Kenya: The Nubian Case' in Brad Blitz and Maureen Lynch (eds), Statelessness and the Benefits of Citizenship: A Comparative Study (Geneva Academy of International Humanitarian Law and Human Rights and the International Observatory on Statelessness 2009) 38, 45.

100 Karan (n 84) 11.

101 Muhammad Rehan Masoom, 'Social Isolation of the Stateless and the Destitute: A Study on the Refugee-Camp and the Sullied Slum of Dhaka City' [2016] Urban Studies Research 1 $<$ https://www.hindawi.com/journals/usr/2016/9017279/>.

102 Amnesty International, 'Effective Human Rights-Based Housing Strategies: Submission to the UN Special Rapporteur on the Right to Adequate Housing as a Component of the Right to an Adequate Standard of Living and on the Right to Non-Discrimination in This Context' (Amnesty International Ltd 2017) 7. 
the authorities' methods of addressing the housing issue have involved coercion, forcible removal and segregation, while the government's financial investment in solving this issue has been negligible. ${ }^{103}$

Instead of receiving support as part of the state's obligation to fulfil the right to adequate housing, stateless populations and those at risk of statelessness face responses ranging from passive neglect to failure to even respect this right.

\section{INTERSECTIONAL IDENTITIES AND STATELESSNESS: FURTHER}

\section{DiscRIMINATION IN THE Right TO ADEQUATE Housing}

The previous section demonstrates that states have failed to comply with their obligations to respect, protect and fulfil the right to adequate housing for stateless persons collectively. But certain groups of stateless persons face further challenges in the enjoyment of this right, encountering additional barriers in initial access and suffering further human rights abuses after this right is violated. One such group are stateless women. They may face discrimination both due to their gender and their lack of a nationality in securing tenure or owning land or property as a result of inequitable laws and biased administration. As a result women make up a disproportionate number of those inadequately housed. ${ }^{104}$ Stateless women face land and property seizure by the state and other third-party actors like all stateless persons, but they also may face seizures by relatives when inheriting land or property due to unequal practices based in law and custom. ${ }^{105}$ Stateless women are often dependent on male family members in gaining access to housing or land, making them more vulnerable to abuse due to inequality in the relationship. ${ }^{106}$ This inequality and resulting dependence also increases the likelihood that women will stay in abusive relationships to avoid displacement or homelessness. ${ }^{107}$ If displaced or already living in substandard housing, women are also disproportionately exposed to gender-based violence and rape, due to a lack of privacy or the necessity that they travel long distances to access water or sanitation services. ${ }^{108}$

Similarly to stateless women, stateless children face additional challenges accessing adequate housing and suffer disproportionately when the state fails in its obligations. As minors, children are dependent on adults to access adequate housing but many are unable to do so. While data is limited, figures estimate that one in three children do not have access to adequate shelter. ${ }^{109}$ There is no data available to show the additional impact that statelessness has on children's access to adequate shelter. Stateless children are often born to stateless parents, who face additional challenges in providing adequate housing for themselves and their offspring. The lack of adequate housing impacts children's ability to study, as they are often attempting to do so in overcrowded spaces, and stateless children may already face challenges enrolling in schools or accessing

103 Perić (n 85).

104 General Comment No 7, UN Doc E/1998/22 (n 13) 115 [11].

105 Miloon Kothari, Study by the Special Rapporteur on Adequate Housing as a Component of the Right to an Adequate Standard of Living on Women and Adequate Housing, UN ESCOR, UN Doc E/CN.4/2005/43 (25 February 2005) 16 [55].

106 ibid 14.

107 ibid.

108 Amnesty International, Insecurity and Dignity: Women's Experiences in the Slums of Nairobi, Kenya (Report, Amnesty International Publications 2010) 7.

109 The State of the World's Children: 2005 (Report, United Nations Children's Fund 2005) 2. 
educational facilities due to their citizenship status and the remote location of their housing. The nature and location of their housing can also limit or deny stateless children the right to engage in play and recreational activities. ${ }^{110}$ Inadequate housing exposes stateless children to disease and health hazards, to which they are already more vulnerable as children, and when they fall ill, stateless children are often denied medical care for lack of a nationality. ${ }^{111}$ Forced evictions and homelessness can be especially traumatic for stateless children, who already face a lack of security and stability in their daily lives, which can further negatively impact their development. ${ }^{112}$

Another group that faces multiple forms of discrimination in accessing adequate housing and suffers disproportionately when that right is violated are stateless persons with disabilities. In some cases, disability can be a cause of statelessness as parents abandon children with disabilities in countries without safeguards in nationality laws for foundlings, while in others, children with disabilities are born to stateless parents or in states with discriminatory nationality laws. ${ }^{113}$ Both stateless persons and persons with disabilities face challenges accessing housing and related services, and these issues are compounded for persons with identities in both groups. Achieving security of tenure can be doubly challenging due to lack of recognition of legal capacity and identity, which leaves them especially vulnerable to forced evictions. ${ }^{114}$ Stateless persons with disabilities can face stigma and fear violence, forcing them to seek shelter in housing that does not afford them adequate privacy or protection, as it may be preferable to alternatives. ${ }^{115}$ Inadequate housing can expose persons with disabilities to additional health hazards, which compound existing medical needs, and they may be unable to seek medical attention when necessary. They may face limited access to the labour market or employment prospects due to their disability and only be able to work in the informal economy due to their statelessness, making it additionally challenging to escape poverty and substandard housing, which itself may be isolated and limit employment opportunities.

Stateless persons who have been displaced, either internally or across borders, also face additional barriers to accessing adequate housing. While it may be intuitive to think that stateless refugees would enjoy greater protections under the refugee framework, this is not necessarily the case with regards to adequate housing. Article 21 of the 1951 Convention Relating to the Status of Refugees ('1951 Refugee Convention') states,

as regards housing, the Contracting States shall...accord to refugees lawfully staying in their territory treatment as favourable as possible and, in any event, not

$110 C R C$ (n 37) art 31.

111 Refugee and Migrant Response in Europe: Ending Childhood Statelessness in Europe (Advocacy Brief, United Nations Children's Fund 2018) 1.

$112 C R C$ (n 37) art 6.

113 See, eg, Greg Constantine, 'We See You' in Laura van Waas and Amal de Chickera (eds), The World's Stateless: Children (Wolf Legal Publishers 2017) 120.

114 Leilani Farha, Report of the Special Rapporteur on Adequate Housing as a Component of the Right to an Adequate Standard of Living, UN GAOR, $72^{\text {nd }}$ sess, UN Doc A/72/128 (12 July 2017) 15 [50].

115 ibid 6 [12]. 
less favourable than that accorded to aliens generally in the same circumstances. ${ }^{116}$

Both the 1951 Refugee Convention and 1954 Statelessness Convention use the same language, and both provide limited protections based on legal presence and only afford safeguards as favourable as those accorded to similarly situated aliens. Stateless refugees in camp settings often occupy shelter that does not meet the requirements for adequate housing in terms of habitability, access to services or location. In urban areas, persons who are stateless and displaced can face abusive rental practices and immediate eviction upon non-payment of rent. Stateless asylum seekers who have had their claims denied can be seen as illegal occupants of both housing and the country in which they find themselves, and thus subject to multiple forms of discrimination. Upon return to their original place of residence, formerly displaced stateless persons can find their homes occupied or destroyed and be unable or unwilling to claim restitution. ${ }^{117}$

Stateless women, children, persons with disabilities and displaced persons face discrimination on multiple fronts in accessing adequate housing and then additional human rights violations resulting from that limited access. For individuals that have identities that further cross these categories, such as stateless women who have been displaced or stateless children with disabilities, they face discrimination on even more numerous fronts. Even though the right to adequate housing for these individuals is protected by multiple human rights treaties, both generally in the ICESCR and specifically in CEDAW, CRC and $C E R D$, they are often unable or unwilling to seek assistance from authorities to address barriers to access or subsequent mistreatment from landlords and neighbours. This may be due to past discrimination and persecution by state agents, and the potential to expose themselves to further harassment for both their lack of a nationality and membership in one or many of these groups. But while the vulnerability of these groups to violations of the right to adequate housing may seem apparent, due to limited data produced by states and little investigation thus far by academics, the true extent of the problem is relatively unknown.

\section{The InTERCONNECTED NATURE OF Violations OF THE Right to}

\section{ADEQUATE HOUSING AND OTHER HuMAN RIGHTS}

While statelessness, identity and inadequate housing are interconnected, inadequately housed stateless persons also face additional and interrelated human rights violations. The denial of the right to adequate housing and the denial of the right to a nationality, both individually and in aggregate, can lead to violations of other fundamental rights. The right to education is one such right that is often violated, due to both nationality status and housing situation. Schools may deny children registration because their settlements lack official status and they cannot provide a qualifying place of residence for enrolment, or they themselves lack legal recognition and cannot produce necessary identity documents. Children may face harassment and mistreatment by classmates and administrators due to their stateless status and their housing conditions. A lack of

116 Convention Relating to the Status of Refugees, opened for signature 28 July 1951, 189 UNTS 150 (entered into force 22 April 1954) art 21.

117 The Right to Adequate Housing (n 11) 27. 
adequate services can impact children's ability to bathe, which can result in stateless children being shunned by classmates and school administrators and, in some cases, being sent home early from school. ${ }^{118}$ Forced evictions, to which stateless families are especially vulnerable, can interrupt schooling or result in indefinite periods when children cannot attend. Due to limited options, stateless children and their families may be forced to live in isolated housing far from schools, where long commutes with limited public transportation options create further barriers to the right to education.

Inadequately housed stateless persons also face barriers to the enjoyment of the highest attainable standard of physical and mental health. Adequate housing has been referred to as an underlying determinant of health ${ }^{119}$ and in General Comment 14, the CESCR notes that ' $[\mathrm{t}]$ he right to health is closely related to and dependent upon the realization of other human rights ... including the rights to ... housing'. 120 Housing conditions can greatly impact both the physical and mental health of occupants by providing or failing to provide security, privacy protection from the elements and disease, and access to services such as water or sanitation. ${ }^{121}$ Stateless persons may fall ill due to their lack of adequate housing and may then be denied medical care both due to their inability to prove their place of residence or their nationality. Forced evictions, to which stateless persons are especially vulnerable, may expose them to violence or environmental hazards requiring medical attention, which they are then denied. The only available housing for stateless persons may be located in segregated areas without access to proper medical facilities, creating further obstacles to enjoying the right to the highest attainable standard of health. In some cases, the state may fail to provide adequate services to stateless communities, resulting in disease outbreak and other violations of the right to the highest attainable standard of health, which the state then uses to justify forced evictions based on public health concerns. While physical health is often given the most attention, the stress, uncertainty, and marginalisation stateless persons forced to live in inadequate housing face on a regular basis due to both their lack of a nationality and their housing conditions can have a serious impact on their mental health as well.

Stateless persons deprived of the right to adequate housing can face denials of not just other socioeconomic rights but also the right to life. The Special Rapporteur on Adequate Housing has called attention to the interconnected nature of the right to life and adequate housing by stating:

Violations of the right to life have been addressed primarily in cases where direct action or deliberate omissions by States have deprived or threatened to deprive individuals of life. The failure of States to address systemic deprivations of the

118 Karan (n 84) 11.

119 Office of the High Commissioner for Human Rights and World Health Organization, The Right to Health (Fact Sheet No 31, June 2008) 3.

120 Committee on Economic, Social and Cultural Rights, General Comment No 14 (2000): The Right to the Highest Attainable Standard of Health (Article 12 of the International Covenant on Economic, Social and Cultural Rights), UN ESCOR, $22^{\text {nd }}$ sess, Agenda Item 3, UN Doc E/C.12/2000/4 (11 August 2000) 2 [3].

121 Bret Thiele, 'The Human Right to Adequate Housing: A Tool for Promoting and Protecting Individual and Community Health' (2002) 92(5) American Journal of Public Health 712, 713. 
right to life tied to poverty, grossly inadequate housing and homelessness have not received the same attention. 122

Stateless persons are one such group that face deprivation of the right to life due to poverty, inadequate housing, and homelessness, due to active state persecution and more passive marginalisation. Some of these threats to the right to life stem from violations of the right to the highest attainable standard of health, while others are unique. Stateless persons experiencing homelessness or living in severely inadequate housing may experience exposure to extreme weather that jeopardises their right to life. Those living in informal settlements, where stateless persons often are forced to reside, face additional hazards such as fire from unauthorised electrical connections or landslides as their housing is built on unstable ground. ${ }^{123}$ As noted earlier, inadequate housing can expose stateless persons to water and sanitation-related illnesses, which in extreme cases can threaten their right to life. Inadequate housing can also increase the incidence of domestic violence, which can constitute a violation of the right to life. ${ }^{124}$ Stateless women and children may be unable to leave situations of domestic violence that threaten their lives due to a lack of community and state support, and instead be dependent on abusive male adults for both housing security and a recognised nationality.

Violations of the right to adequate housing and its intersection with other human rights, such as the right to education, the highest attainable standard of health, and life, all contribute to higher rates of poverty for stateless persons. Segregation in housing or being forced to live in isolated areas without public transportation, combined with a lack of identity documents or documents proving place of residence, can severely limit access to employment and employment opportunities. A lack of services can require that stateless persons spend much of their time collecting water or firewood instead of earning income, and a lack of a nationality can contribute to stateless persons being unable to qualify for government benefits. Limited educational opportunities due to both inadequate housing and the lack of a nationality can limit future earning potential, condemning children to lifetimes of poverty. Denial of access to healthcare due to both stateless status and housing situation can force individuals to spend their lives battling illness, limiting initial options for employment and creating obstacles to maintaining steady jobs. Challenges to simply staying alive, stemming from inadequate housing and lack of a nationality, can also limit stateless persons' opportunities for employment, which would help them escape poverty. Similar to how identities interact and have compounding effects on the enjoyment of the rights of stateless persons, violations of the right to adequate housing and the right to a nationality can interact in complex ways and be the cause of additional rights violations.

\section{Shortcomings OF The PAST AND A LOOK TO THE FutURE}

While stateless persons are generally among those most disadvantaged in societies and should thus receive some level of priority consideration in housing

122 Leilani Fahra, Report of the Special Rapporteur on Adequate Housing as a Component of the Right to an Adequate Standard of Living, UN GAOR, $71^{\text {st }}$ sess, UN Doc A/71/310 (8 August 2016) 2.

123 ibid 7.

124 ibid 10. 
strategies, ${ }^{125}$ this analysis demonstrates that this is rarely the case. Instead, they face state responses ranging from marginalisation to direct discrimination. Furthermore, the reliable data that would be necessary to understand the extent of the problems and ensure the inclusion of stateless persons is scarce. Data on inadequate housing and statelessness as separate issues is insufficient and combined is nearly non-existent, as both inadequate housing and statelessness are largely invisible issues. States might be hesitant to invest in data collection because the act of mapping can be time-consuming and expensive, or because collected data might further obligate states to take action. Additional challenges come from individuals' potential unwillingness to identify with these categories, which often carry stigma or simple unawareness. Definitions of who fits these categories may be further complicated by incorrect interpretations of terms associated with statelessness and with inadequate housing, along with changing situations. Regardless of these limitations, states' immediate obligations according to CESCR General Comment 4 include determining the full extent of homelessness and inadequate housing within their territories. ${ }^{126}$ Provisions of the 1961 Convention on the Reduction of Statelessness obligate states to prevent and reduce statelessness, and doing so requires identification of stateless persons within their borders. ${ }^{127}$ While progress has been made recently due to technological advances and increased emphasis on mapping, it has been noted that there is 'limited availability of empirical and quantitative data with which to evaluate housing in rapidly urbanizing countries', 128 and regarding statelessness, UNHCR's Global Trends Report notes that 'fewer than half the countries in the world have any government data on stateless populations'. ${ }^{129}$ In order to address these rights violations, their true extent and the degree to which they overlap must first be understood.

States' obligations to stateless persons regarding the right to adequate housing go beyond simply mapping the extent of the problem. The 1954 Statelessness Convention is often the starting point for understanding the protections owed to stateless persons, but because its safeguards allow for distinctions between nationals and non-nationals and are provisional on stateless persons' presence being considered lawful, other international treaties provide for greater protections. Given the ICESCR's recognition of 'the right of everyone to an adequate standard of living for himself and his family, including ... housing, and to the continuous improvement of living conditions' 130 and the CESCR's further clarification of state obligations for all persons in the progressive realisation of this right, the Covenant provides a strong foundation for understanding state obligations to stateless persons. Furthermore, given the ICESCR's widespread ratification when compared to the 1954 Statelessness Convention, ${ }^{131}$ it becomes

125 General Comment No 4, UN Doc E/1992/23 (n 9) 118 [13].

126 ibid.

127 Convention on the Reduction of Statelessness, opened for signature 30 August 1961, 989 UNTS 175 (entered into force 13 December 1975).

128 Robin King et al, Confronting the Urban Housing Crisis in the Global South: Adequate, Secure, and Affordable Housing (Working Paper, World Resources Institute 2017) 7 $<$ https://www.wri.org/sites/default/files/towards-more-equal-city-confronting-urbanhousing-crisis-global-south.pdf $>$.

129 Global Trends (n 23) 51.

$130 \operatorname{ICESCR}$ (n 32) art 11.

131 'Chapter IV Human Rights: 3. International Covenant on Economic, Social and Cultural Rights, New York, 16 December 1966', United Nations Treaty Collection Status of Treaties (Web Page) <https://treaties.un.org/Pages/ViewDetails.aspx?src=IND\&mtdsg_no=IV$3 \&$ chapter $=4 \&$ clang $=$ en $>$. 
all the more important as a way to guarantee the enjoyment of the right to adequate housing. Other widely ratified treaties, including but not limited to, $C E D A W, C R C$ and $C R P D$, further clarify states' duties to specific populations regardless of nationality, and these groups often face challenges enjoying both the right to a nationality and the right to adequate housing. These obligations include respecting, protecting and fulfilling the right to adequate housing for all persons. To respect this right for stateless persons, states must comply with their immediate obligations to end discrimination in housing, end forced evictions carried out in violation of human rights principles and stop the destruction of homes, as these acts condemn stateless persons to further marginalisation and poverty. To protect this right, states must prevent and address discrimination by non-state actors, guarantee the non-discriminatory provision of services if not provided by the state and ensure that third-parties do not carry out forced evictions. Progressive realisation of the obligation to fulfil this right includes the development of national housing plans that target areas where there are large concentrations of stateless persons and the creation of avenues for remedy if the state fails to comply with its obligations through courts, national human rights institutions or local housing councils. ${ }^{132}$

While these treaties recognise the interconnected nature of human rights, state policies and programs that aim to address the right to adequate housing often fail to consider the additional challenges presented by statelessness and vice versa. Without a recognised nationality, stateless persons are often unable to benefit from government programs designed to help those in inadequate or unstable living situations such as housing programs, subsidies and access to emergency shelter. Conversely, plans aimed at reducing statelessness have failed to consider how inadequate or informal housing can create challenges in qualifying for and participating in these programs. Facilitated naturalisation for stateless persons often requires the demonstration of lawful and habitual residence, which those living in informal settlements often cannot provide, as neither their presence nor their residence is considered legal. ${ }^{133}$ Even if plans to address the right to adequate housing are successful, without holistic thinking, those benefiting might still be stateless and suffer accompanying discrimination, marginalisation and human rights violations, such as the right to education or the highest attainable standard of health. Similarly, if only addressing the right to a nationality, those benefiting might still live in segregated or substandard housing which provides its own basis for discrimination and its own challenges in the enjoyment of human rights, due to its isolated nature without access to services or opportunities and exposure to hazards. For persons living at the intersection of multiple human rights violations, solutions that are not comprehensive are hardly solutions at all.

While numerous treaties recognise the interconnected nature of human rights violations and the identities of those most vulnerable to abuses, ratification has

132 Human Rights Council, Report of the Special Rapporteur on Adequate Housing as a Component of the Right to an Adequate Standard of Living, UN GAOR, $37^{\text {th }}$ sess, Agenda Item 3, UN Doc A/HRC/37/53 (15 January 2018) 16 [112].

133 Eva Mrekajová, 'Facilitated Naturalization of Stateless Persons' (2014) 19(1-2) Tilburg Law Review 203, 205; Ivana Stankovic, 'CESCR's Recommendations - Serbia to Ensure Effective Access to Personal Documents for Roma and Displaced Persons, and in the Meantime to Facilitate Their Access to Economic, Social and Cultural Rights' European Network on Statelessness (Blog Post, 4 July 2014) $<$ https://www.statelessness.eu/blog/cescr\%E2\%80\%99s-recommendation-\%E2\%80\%93serbia-ensure-effective-access-personal-documents-roma-and-displaced $>$. 
not guaranteed the fulfilment of state obligations. The Sustainable Development Goals ('SDGs') provide another avenue for recognising the importance of addressing both statelessness and inadequate housing in order to end poverty, but given their non-binding nature, they too have their limitations. While multiple goals and targets relate to reducing statelessness, ${ }^{134}$ Goal 16.9 ('provide legal identity for all, including birth registration') is the most explicit about states' obligations to prevent and reduce statelessness. ${ }^{135}$ Similarly, Goal 11.1 ('ensure access for all to adequate, safe and affordable housing and basic services and upgrade slums' by 2030) most clearly recognises the importance of adequate housing. ${ }^{136}$ The SDGs make no distinction based on nationality and emphasise states' obligations to ensure access to adequate housing for all. Furthermore, Goal 11.1 and its associated goal's emphasis on participatory settlement planning is especially important for stateless persons, who are often excluded from decision-making processes and whose unique concerns thus go unnoted. Additionally, the Habitat III New Urban Agenda reaffirms the SDG's commitments to more inclusive planning by bringing together UN agencies, government, and civil society organisations. ${ }^{137}$ While it makes no reference to statelessness, its emphasis on dialogue with all members of society including 'refugees, internally displaced persons and migrants, regardless of their migration status, without discrimination based on race, religion, ethnicity, or socioeconomic status' ${ }^{138}$ to address the housing needs of those in vulnerable situations may be understood to extend to stateless persons. ${ }^{139}$ This inclusivity can help identify shortcomings and structural weaknesses of existing policies and their disproportionate impact on stateless persons' dignity and enjoyment of other human rights. Participatory planning might begin to reduce incidences of policy measures that ignore the intersectionality of human rights violations or the underlying discrimination that causes them. This, in turn, might allow for the SDGs to meet their goals of leaving no one behind and 'reach[ing] the furthest behind first', ${ }^{140}$ which must include stateless persons.

This analysis has focused on state failures in the inclusion of stateless persons in housing strategies and potential means for participation, but has also stressed that in order to ensure true inclusion, the underlying causes of statelessness must be addressed. Each state has unique circumstances and challenges surrounding both the realisation of the right to adequate housing and the right to a nationality, which will lead to differing responses and are worthy of future analysis on a state-by-state basis. The challenges faced by nomadic populations in both gaining state recognition as citizens and having their land and housing rights respected and realised are of particular concern and deserve further investigation. Additional analysis might also explore the connection between statelessness and

134 de Chickera (n 20) 5.

135 Transforming Our World: The 2030 Agenda for Sustainable Development, UN Doc A/RES/70/1 (21 October 2015) 21, 25 ('Sustainable Development Goals'). United Nations High Commissioner for Refugees, 'The Sustainable Development Goals and Addressing Statelessness' (Briefing Note, United Nations High Commissioner for Refugees 2017) 4.

136 Inter-Agency Expert Group on SDG Indicators, 'Goal 11: Make Cities and Human Settlements Inclusive, Safe, Resilient and Sustainable' (United Nations Statistics Division 3 March 2016) 2 <https://unstats.un.org/sdgs/files/metadata-compilation/Metadata-Goal11.pdf $>$.

137 United Nations Conference on Housing and Sustainable Urban Development, New Urban Agenda (Habitat III Secretariat, United Nations 2017) iv.

138 ibid 14 [42].

139 ibid 13.

140 Sustainable Development Goals, UN Doc A/RES/70/1 (n 135) 3 [4]. 
urbanisation; as stateless persons face violations of the right to adequate housing in rural areas due to agricultural or infrastructure projects, they might be pushed to urban areas where they face challenges enjoying the right to adequate housing in a new context. To truly create greater inclusion of inadequately housed stateless persons, those experiencing rights violations should be centred and their voices amplified in both policy making spheres and academia. There is undeniably much room for further investigation to understand the extent to which statelessness and inadequate housing intersect, as well as other human rights abuses and marginalised identities. This analysis aims to be a starting point for those future conversations. 